\title{
Subjektivering og nye identiteter \\ - en psykologi i et pædagogisk felt
}

Af Dorte Marie SøndergaArd

Den danske konsforsker Dorte Marie Søndergaard boldt sin tiltrodelsesforelesning som professor $i$ socialpsykologi på Danmarks Padagogiske Universitet den 25. april 2003

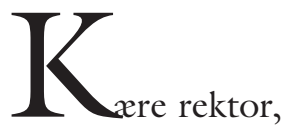

kolleger, studerende og øvrige tilhørere. Jeg skal i denne inaugurale forelæsning forsøge at give en fornemmelse af, hvad det er for en type faglighed, Danmarks Pedagogiske Universitet har prioriteret ind i realiseringen af sin profil i og med universitetets besættelse af professoratet i socialpsykologi 1. oktober 2002.1 Det vil jeg gøre ved først meget kort at tegne konturerne af den forståelse af pædagogik, som placerer fagligheden ind i sammenhængen, og dernæst ved at forsøge at åbne nogle af faglighedens centrale perspektiver gennem definitioner og eksempler.

Prdagogiske universiteter, 'universities of education', er jo ikke nogen dansk opfindelse. De ligger spredt ud over det meste af, i hvert fald den angelsaksiske verden. Alligevel har jeg herhjemme med mellemrum mødt nogle lidt undrende reaktioner over, at man prioriterer et universitet til "så smalt et felt", som det hedder. Det er klart, at et pædagogisk universitet med streg under 


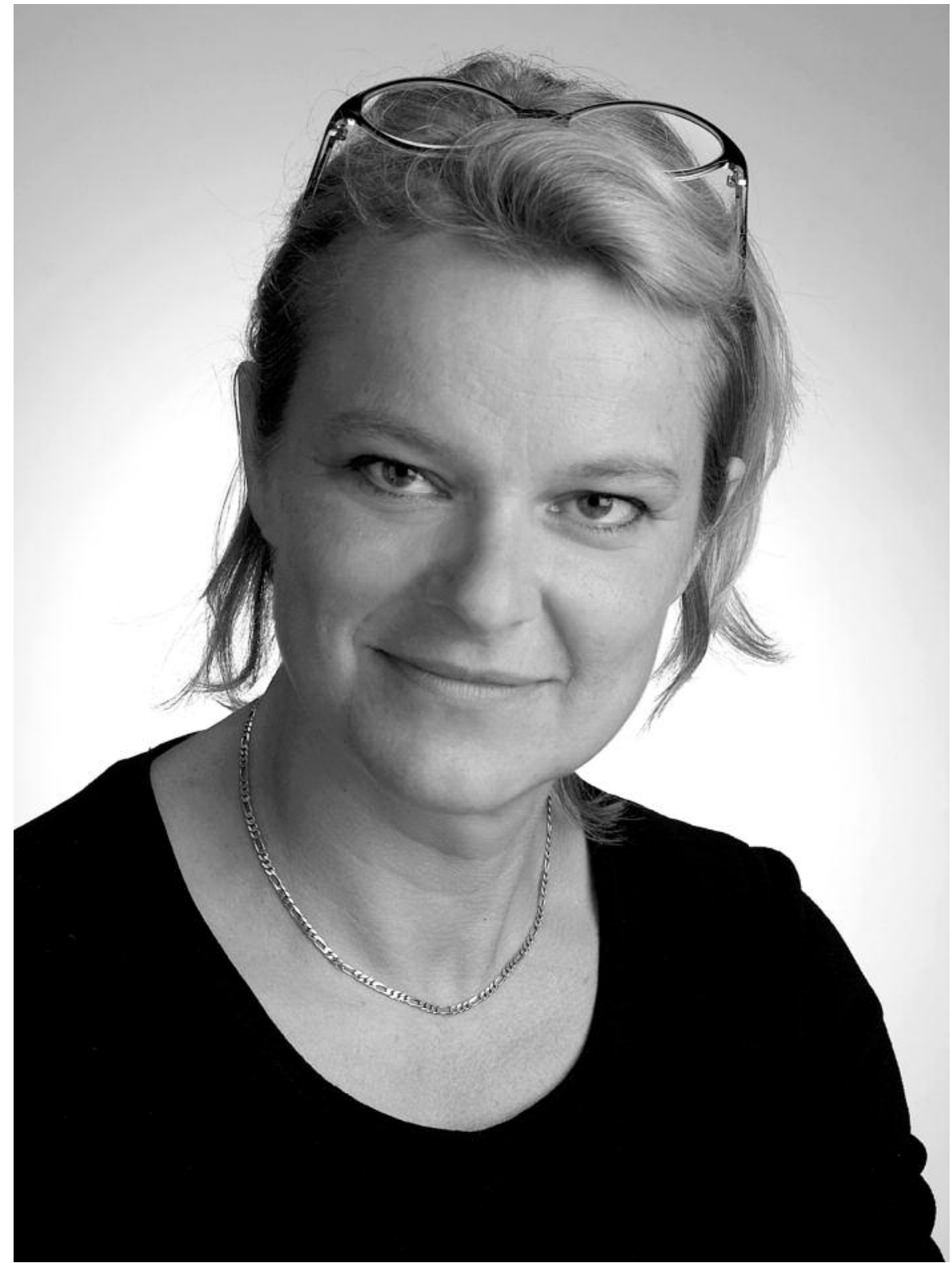

Dorthe Marie Sondergaard 
universitet kun har sin berettigelse, hvis man opererer med en meget bred og mættet forståelse af, hvad det pædagogiske går ud på. Universiteter funderes jo netop ikke på helt smalle genstandsfelter eller på smalle fagdiscipliner. Institutter bæres af discipliner og deres historisk konstruerede opfattelser af, hvordan genstandsfelter bør afgrænses. Men universiteter må have mere omfattende foci for at leve op til begrebet universitas: helhed. Når det pædagogiske derfor forstås med vægten lagt på en formulering om det menneskeligt tilblivende det vil sige i relation til de processer, hvorigennem mennesker dannes som handlende, reflekterende og interagerende væsener - så bliver det relevant med et pædagogisk universitet. Det bliver endog meget relevant i den aktuelle historiske og samfundsmæssige kontekst.

Man må så fokusere forskellige grader af konation ind i processerne. Man må tænke forskellige grader af vilje og målretning ind som del af disse tilblivelsesprocesser. Men for at sådant et intentionelt aspekt af processerne kan forstås kvalificeret, så er det nødvendigt samtidig at studere det, der fremmer, hæmmer, bryder, går på tværs af, bidrager til tilblivelsen - alt det der med andre ord bliver medbestemmende for intentionalitetens eksistens og virke, sådan som den nu vil være rettet mod givne tilblivelser. Det indebxrer blandt andet, at man må studere intentionalitetens konstruktion og intentionalitetskonstruktionens møde med andre virksomme konstruktioner inden for de konkrete felter, hvor tilblivelsen foregår; og de felter er mangeartede.

Det primære i forståelsen er altså, at fokusere menneskelig tilblivelse ind i et mere omfattende perspektiv, der også gør intentionaliteternes konstruktion og virke forståelige som dele af mere omfattende dannelses- og tilblivelsesprocesser. Sådan en forståelse kan rejse en række spørgsmål. ${ }^{2}$ $\mathrm{Og}$ jeg foregriber straks ved at sige: Vi mister ikke af den grund hverken folkeskolen eller didaktikken. Folkeskolen er en uhyre central tilblivelseskontekst. Den er bare ikke den eneste interessante i den nye universitære sammenhæng. Didaktikken er nødvendig, men den er een blandt mange typer af tilblivelsesprocessering, nemlig en konkret bevidst redskabsrefleksion rettet mod særlige dele af dannelsesprocessen. Vi mister ikke specialpædagogikken, et vigtigt satsningsområde på DPU, igen en bevidst og målrettet indsats, der rummer relaterings- og struktureringsformer, som har netop skæve og komplicerede subjektiveringsprocesser som sit refleksions- og indsatsområde. Og lytter man til Niels Egelund, professor på Institut for Padagogisk Psykologi, er det et felt, som i høj grad har brug for studier af, hvordan det skæve formes/konstrueres og ikke bare forskning, der måler og møder det, der på forhånd er defineret som værende det skæve. Vi mister ikke noget af alt dette. Det, vi gør med denne brede forståelse af pædagogiske processer, er at tegne en mere omfattende kontekst op for fx de netop nævnte områder og gøre dem til væsentlige interagerende felter blandt de mange øvrige felter, universitetets kundskabsambitioner er rettet mod.

Inden for denne omfattende kontekst foretager vi så arbejdsdelingen mellem de mange fokuseringer og de mange forskelligartede tilgange. Det er også her navnet på Institut for Padagogisk Psykologi, får mening som en relativt afgrænset størrelse. Havde det navn indikeret, at det eneste vi skulle beskæftige os med, var psykologi af den art, der kunne bruges i forhold til didaktiske overvejelser eller eventuelt til diagnostik i forhold til de enkeltindivider, der skulle mødes med didaktiske virkemidler, så ville det blive en meget begrænset affære set i relation til de muligheder, psykologien rummer som disciplin. Vi skal gøre de ting, men vi skal ikke kun gøre de ting. Pædagogisk psykologi kan mest frugtbart forstås som psykologien anvendt i sin fokusering på menneskelige tilblivelsesprocesser i mere eller mindre eksplicit styrede og organiserede kontekster, og det igen åbner for den 
teori/paradigmepluralisme og den genstandspluralisme, som vil være mest hensigtsmæssig, hvis man skal udnytte disciplinens potentialer optimalt $\mathrm{i}$ forhold til et universitet som dette. Universitet - universitas - helhed.

\section{BEGREBSAFKLARING}

Pædagogisk åbnes altså her i sin allerbredeste definition med vægten lagt på kontekstspecifik menneskelig tilblivelse. Og herfra kan der så foretages yderligere specificeringer $\mathrm{i}$ forhold til fokus og dermed afgrænsning af begrebssystemer. I en psykologfaglig kontekst bliver det nærliggende at foretage det sidste stykke af den rejse ind $i$ en begrebstradition, der viderefører perspektivet med et fokus på subjektsiden i fænomenet, men på en måde, der netop understreger proces, bevægelse, relation og kontekst. I en sådan fokusering er det vigtigt at undvige individualisering, essentialisering og dekontekstualisering. Dette vil være een af de nærliggende måder, begrebsspecificeringerne kan foretages på, men naturligvis ikke den eneste mulige. Efter min mening skærpes dette fokus meget smukt i sin proceskarakter gennem subjektiveringsbegrebet, sådan som det er hentet i de videreudviklinger af blandt andet den foucault'ske tradition, der især er fundet sted inden for feministisk teori og diversitetsforskning, samt inden for psykologi- og uddannelsesfaglige og typisk empiriske forskningstraditioner. Navne som Judith Butler, Patti Lather, Bronwyn Davies, Hanne Haavind, Margareth Wetherell, Ann Phoenix m.fl. er nærliggende at nævne i den sammenhæeng.

Det er altså ikke en Foucault/Butler-teori, der er på tale, men en videreudvikling af nogle af de grundlæggende perspektiver, der kan hentes ud af deres forfatterskaber og derpå en sammentænkning af dem med en empirisk forskningstradition, som igen har rødder mange andre steder, faktisk så forskellige steder som i sovjetpsykologien og etnometodologien. De perspektiver, der hentes fra den tradition, drejer sig i denne sammenhæng om diskursiv konstituering, om forståelsen af diskursiv magt som konstitueringsvilkår for subjektet og så selvfølgelig det, helt gennemført at holde fast i en deesentialiserende analytisk tilgang til den empiriske virkelighed.

Den grundlæggende forståelse af subjektbegrebet baserer sig i korthed på den dobbelte betydning, der knytter sig til begrebet på både engelsk og fransk, nemlig den der peger på subjektets samtidige underkastelse og kommen til eksistens (genkendelse, identitet, handling og orientering) gennem diskursiv indlejring. Med den forståelse problematiseres også en eventuel entydig dikotomi mellem undertrykkelse og frihed. Den foucault'ske magtforståelse opløser som bekendt denne dikotomi. Men denne dobbeltsidede bestemmelse af mennesket finder man faktisk i lidt varierende udgaver i mange andre faglige traditioner også. Det er en forståelse, som mange forsøger at kvalificere, og som der, for så vidt, ikke er nogen grund til at forestille sig, at Foucault har opfundet i ophøjet isolation. Man finder den i dele af den antropologiske traditions tænkning i mennesket som grundlæggende kulturelt væsen (Clifford Geertz, Richard Schweder. Herhjemme: Kirsten Hastrup, Cathrine Hasse). Man finder væsentlige aspekter af den i de kulturpsykologiske sammentænkninger af den antropologiske og den sovjetpsykologiske forståelsesform (Jerome Bruner, James Wertsch) med deres udpegninger af meaning-making processes, narrativ erkendelse, multivoiced meaning (Bakhtin) etc., som nogle af de begrebsmæssige specialiseringer. Man finder den i den kulturhistoriske skole, igen en videreudvikling af sovjetpsykologien, herhjemme med navne som Ole Dreier, Morten Nissen og Charlotte Højholt; og man finder den inden for flere andre traditioner. Jeg nævner her bare kort nogle af dem for at appellere til genkendelse fra forskellige perspektiver i forsamlingen. Hver af 
disse traditioner er selvfølgelig bøjet og tonet på forskellige måder, deres hang til begrebslige fikseringer, universalisering og småessentialiseringer varierer etc., men ikke desto mindre deler de en frelles ambition om, på en eller anden måde, at gribe relationen mellem individet og det socio-kulturelt kontekstuelle, (det samfundsmæssige, det diskursive) som en indre sammenhæng. Sådan nogle typer af vinklinger retter den empirisk analytiske interesse nogle bestemte steder hen. Og som sagt er det den særlige begrebslige fortætning i det her omfattende teoretisk/metodologiske felt, der centrerer sig omkring subjektiveringsbegrebet, som jeg har fundet særligt analytisk frugtbart ind $\mathrm{i}$ mellem drejende over i Jerome Bruners konceptualiseringer omkring 'meaning-making processes'.

Med det perspektiv bliver der tale om en analytisk søgen efter det kulturelt eller diskursivt indforståede - det selvfølgeliggjorte mønster af betydninger og praksisser, som konkrete subjekter skabes igennem og skaber sig igennem. Det sidste er lidt vigtigt, eftersom der hverken er tale om en deterministisk tænkning eller om en tænkning i isoleret selvkonstruktion.

Det, der er tale om, er:

- at mennesker tilbydes diskursive konstitueringsvilkår,

- at sådan nogle konstitueringsvilkår altid er i proces og bevægelse, fulde af modsætninger og paradokser, de udgør lag på lag af kodesystemer, som agerer med og mod og igennem hinanden; som ydermere transformerer hinanden,

- at mennesker derfor subjektiverer sig (igennem) modsætningsfulde diskurser i bevægelse, og at de gennem deres subjektiveringer selv bidrager til bevægelserne. Måderne de agerer på, måderne de tager diskursive konstituenter i brug på, måderne de arbejder konstituenterne videre på, citerer dem, modsiger dem, kombinerer dem på - alt det fungerer medskabende $\mathrm{i}$ forhold til de diskursive betingelser, der fortsat vil udgøre ikke bare deres egne, men også andre tilkommende deltageres subjektiveringsvilkår. Og det er her Bruners begreb om 'meaning-making' kan blive ganske præcist, fordi fokuseringen på den enkeltes egne deltagelse i meningsskabelsen, og i skabelsen af orden, er enormt vigtig at få med i analyserne som en samtidig bevægelse i den diskursive konstituering. Meningsskabelse kan også specificeres som konnotationspraksisser - et begreb jeg kommer til at bruge om lidt,

- og som den fjerde og sidste pointe i oplistningen: der er tale om, at alt det her har en både synkron og diakron interaktionsradius med andre erfarings- og subjektiveringsarenaer. Det vil sige, at der er en historisk biografisk dimension at tage højde for; der er en samfundshistorisk dimension at tage højde for, og der er en interaktion mellem forskellige aktuelle arenaer at tage højde for, når det drejer sig om at forstå den diskursive processering empirisk - at analysere den empirisk. Pointen er blot, at hierarkiet eller knudepunkterne mellem disse dimensioner ikke kan bestemmes forud for en empirisk analyse. Og nu skal jeg blive mere konkret!

\section{EKSEMPEL: ET SKOLERUM}

Hvordan skal vi så forstå den flok, der marcherer ind ad døren i l. klasse og ud af den igen i 10.? Er det 22 individuelle personer parate til at åbne deres mentale apparater for implantering af forskellige former for kompetence - neutralt og professionelt tilbudt af allerede tidligere kompetenceberigede folkeskolelærere? Er det sådan, vi skal forstå dem? Som små individer med en aflang åbning her i højre side af hovedet, hvor man kan lægge kompetencedisketten ind, foretage en række rutinehandlinger, for derpå at forvente en effekt i form af ligeligt kompetenceberigede små individer efter- 
følgende? Er i øvrigt dette fænomen, kompetence, noget, vi må forstå som neutralt, og som en ting, der kan overføres relativt direkte mellem mennesker? Og er det videre sådan, at når vi ikke ser de 22 små individer senere bevæge sig lige kompetenceberigede ud af rummet igen, så er det, fordi der var noget i de individuelle receptionsapparater, som var mangelfuldt, og at det derfor er mest hensigtsmæssigt at foretage nogle individuelle målinger på receptionsapparaterne med henblik på at kompensere for manglerne næste gang disketten lægges ind - hvad enten den nu lægges ind hos de samme individer eller hos individer, der kan identificeres som nogle af samme slags? Er det sådan, vi skal tænke?

Det første vi skal tænke, er selvfølgelig, at sådan her er der ikke nogen, eller i hvert fald kun meget få, der tænker. Det her er en karikatur på en individualiserende forståelse af mennesket. Det individualiserende perspektiv ligger imidlertid udbredt i mindre ekstreme varianter som diskursivt tilbud i både videnskabelige og hverdagsdiskursive forståelsesformer. Så spørgsmålet er stadig relevant: Er det sådan, vi skal tænke? Ja, det kan vi godt! Eller man kan sige, at det er en forståelse, som faktisk må tages helt alvorligt som det, den er: En individualiserende forståelse med en lang historie bag sig, med mange undervisningsmæssigt strukturelle effekter bygget op omkring sig og dermed baseret på et relativt stort apparat af paratheder til at se, forstå og gribe ind i forhold til små mennesker. Det er en forståelse, der skaber subjekter, og som subjekter tilbydes at skabe sig indenfor. Derfor er det en forståelse, der udgør en realitet i verden. Den er virkelighedskonstituerende; og derfor må der også være nogen, der kan den, og som kan arbejde med den både $\mathrm{i}$ dens specialiserede udgave og med et kritisk blik for den mere omfattende kontekst, der sætter betingelserne for og konstituerer det specifikke. Men det betyder ikke, at vi ikke kan skabe og tilbyde andre forståelser. Det betyder heller ikke, at vi skal afholde os fra at forestille os, at disse forskelligartede forståelser gradvist vil kunne nærme sig hinanden og berige hinanden, så den kompleksitet, vi opnår, bliver stadig mere omfattende i forhold til arten af aspekter, som kan medtænkes.

Men for at vende tilbage til muligheden for andre forståelser: Man kan også gøre noget andet. I stedet for at sige, at her har vi 22 små individuelle personer åbne for kompetenceberigelse - så kan man måske sige, at det er noget andet, der vandrer ind ad døren. Man kan sige: Ind ad døren marcherer 22 små krydsfelter mellem varierende former for diskursive brydninger, sådan som de aktuelt skabes i det rum, de træder ind i, ved hjælp af brydningerne mellem:

- tilstedeværende diskurser (skolediskurser, elevdiskurser, kønsdiskurser, læringsdiskurser etc.),

- biografisk tilegnede og medbragte diskursive muligheder, noget der igen varierer med de individer, der træeder ind,

- alt dette blandet og brudt med diskurser medbragt fra andre aktuelle arenaer (familie, medier, sport, andre børnegrupper etc.).

Det er altså i den forståelse 22 hver især unikke små diskursive krydsfelter, vi har med at gøre. Og hver og en af de 22 små er i færd med at bevæge sig i forhold til de subjektpositioner, rummets diskurser og dets aktører tilbyder dem at genkonstituere sig igennem. Subjektiveringen er en proces, der allerede er $\mathrm{i}$ gang, når de 22 træeder ind i rummet, men det er en proces som fortsættes og retningsgives på særlige måder alt afhængigt af, hvilke muligheder der åbnes i netop dette konkrete skolerum for at agere i felterne af diskursive brydninger.

SOCIO-KULTURELLE KATEGORIER

Nogle af de diskursive struktureringer, der 
samler tilblivelsesbetingelserne i formationer, som konkrete mennesker tilbydes at orientere sig og subjektivere sig igennem nogle af de betingelser kan studeres som socio-kulturelle kategorier, det vil sige som samlinger af selvfølgeliggjorte handle- og betydningsformer knyttet til forestillinger om særlige kategorier, særlige typer af mennesker. Vi kender umiddelbart mange af de store kategorier som køn, etnicitet, race, alder osv. Men det interessante er jo altid at se, hvilke kategorier der gøres relevante for subjektiveringsprocesser i konkrete kontekster, i helt konkrete handlefelter. Nogle af dem kan være 'elev', 'lærer', 'medarbejder', 'mening medarbejder', 'leder', 'mellemleder'. Eller de kan formes som endnu mere lokale udgaver af typen: 'nørd', 'pop-tøs', 'bitch', 'perker'. I organisationernes ledelsessammenhæng kan de hedde: 'sen performer', 'den drive-svage', 'kynikeren' osv. Der kan med andre ord være tale om helt specifikke kategorier, som lokalt agerer enormt meningsmættede. Sådan nogle meningsfortætninger og meningstilskrivninger er altid i bevægelse. Der er en løbende interaktion og gensidig indsivning og justering små og store kategorier imellem.

At studere denne form for fænomener, kategorier og subjektiveringseffekter betyder, at man har et genstandsfelt, der består af bevægelseslinier. Og det kræver en meget høj grad af teoretisk og metodologisk refleksion at agere forskningsmæssigt i feltet uden at gøre vold på bevægelsen. Mange vil jo som bekendt gerne fiksere bevægelser (ikke mindst forskningsrekvirenter eller journalister), men kunsten som forsker inden for denne tradition består $i$ at minimere den trang til fiksering så meget som muligt. Socio-kulturelle kategorier stiller identiteter til rådighed, som igen inviterer til subjektivering af særlige individer afhængigt af mange ting. Køn stiller identiteterne pige og dreng, kvinde og mand med et utal af underkategorier til rådighed. $\mathrm{Og}$ dermed åbnes der til subjektiveringstilbud af en bestemt karakter. Med en af Dorthe Staunæs' fine metaforer kan man sige, at de sociokulturelle kategorier arbejder gennem lange fangarme med sugekopper på, som suger individer til sig og installerer dem i særlige identiteter og positioner. Kategorierne suger; de hverver individer. $\mathrm{Og}$ ud af det kommer noget, som vi hverdagsdiskursivt opfatter som udtryk for individuelt iboende anlæg og træk: Som om vi bærer rundt på afgrænsede identitetspakker, færdiggjort i en bestemt alder og parate til at blive foldet ud i enhver tænkelig sammenhæng. Det er jo i grunden en ganske interessant forskydning af forståelsen: Kategorierne subjektiverer $\mathrm{i}$ en aldrig afsluttet proces, og hverdagsdiskurserne tilsiger os, at det vi ser, er en udfoldelse af indre afgrænsede og fikserede identitetspakker.

\section{DAGINSTITUTIONERS SMÅ MASKULINITETSGIDSLER}

Hvis I går ind i en daginstitution og kigger på en flok 4-5-årige, så vil I se en variationsbredde i, hvordan - nej, ikke hvordan alder kan gøres, i forhold til alder bliver der helt klart rettet ind, så alder gøres korrekt, og der tilkaldes eksperter, hvis det ikke sker - men man vil stadig se en vis variation $i$, hvordan køn kan gøres. Og her tilkaldes der sjældent eksperter, hvis ikke kategorierne gøres ordentligt. I hvert fald kalder man problemet noget andet, hvis man gør det. I hvervningen til kønskategorierne er det børnenes gensidige spejlinger og reguleringer, der udgør langt den stærkeste subjektiveringsmotor, sammen med medierne. I sådan en flok 4-5 årige vil der altid være nogle, som er suget ind i en grad, der kan få os til nærmest at se dem som en form for gidsler, fx som maskulinitetsgidsler. De bliver gidsler for kategoriens reproduktion. De hverves til at personificere den udtrykte bekræftelse af kategoriens kernekarakter, men også dens karakter af immanens. Der ligger som bekendt meget angst i opbygningen af maskulinitet. Og I vil se de her små fyre stavre rundt udstyret med ubegri- 
belige mængder af våben med et relativt entydigt ordforråd, som dog er særlig udbygget, når det drejer sig om at benævne alt det, der er farligt, og som må angribes og destrueres eller kontrolleres ved hjælp af fælder, lænker og fængsler. Det, der skal angribes, destrueres eller kontrolleres kan enten være fjendtlige udtryk for maskulinitet eller det, der kan anfæegte ens maskulinitetstilhør, nemlig det feminint konnoterede. Og det er klart, at små feminint tegnsatte individer, piger, kan være nogle af de mere farlige fænomener i feltet. Bemærk at på dette tidspunkt i bevægelsen inden for alderskategorien er maskulin dominans ikke nogen selvfølge. Når sådan nogle små maskulinitetsgidsler nogle gange får øje på de udtryksformer og legemuligheder, der er konnoteret på måder, som afskærer dem fra at deltage, så er det interessant at observere deres bevægelse i mulighedsfeltet. [Forelæseren agerer maskulinitetsgidsel, der tænker:] "Det der lego-slot derovre - det er bare enormt flot - men det er for lyserødt shit! - man er afskåret fra at inddrage det i sine lege - hvad gør man så?”

Ja, hvad gør man så? Der er tre umiddelbare muligheder vis a vis dette problem, tre umiddelbare positioneringsstrategier:

\section{Man kan vende ryggen til. Psykoanalyti-} kerne ville tale om begærsfortrængning, og så ville de begynde med forskellige former for seksualiserende toninger, som naturligvis er helt unødvendige her. Poststrukturalisterne ville sige: Der er tale om en lokal abjicering. Judith Butler er i sin bog The Psychic Life of Power nået dertil, hvor hun lægger et depressionsaspekt ind i forlængelse af denne diskursivt faciliterede afvisningsnødvendighed. Ifølge hende indebærer det en sorg at måtte give afkald på livsmuligheder på grund af kategoritilhør. Men det er en sorg, der ikke kan sørges, fordi den som en åben sorg ville fungere delegitimerende for ens kategorielle genkendelse og dermed identitet og eksistentielle anerkendelse. Butler har nogle udvik- linger omkring begrebet melankoli, som man kan mene forskellige ting om. Jeg mener fx., at hun med sine ideer bevæger sig lige på kanten af en teoretisk konkretisering, der kan vække bekymring, fordi den tenderer en grad af generalisering og universalisering, som kan komme til at fungere overgribende i forhold til det, som vi i sidste ende (altså ikke filosofferne, men vi andre) gerne vil forstå, nemlig den empiriske virkelighed i al sin modsætningsfuldhed og forskellighed. Men det en mere omfattende metodologisk diskussion, der er tale om her; og det er ikke usandsynligt, at jeg reparerer en lille smule på hendes problem ved at tilføje de næste to muligheder. Den første mulighed er altså at vende ryggen til: Man ser ikke legoslotte.

2. Den anden mulighed er at destruere det, man ikke har adgang til. Det vil sige aktivt at fjerne målet for ens begær, ikke bare ved at vende ryggen til, men ved at forsøge at destruere det. Prøv her også at tænke i etnicitetskategorier, og i tendensen blandt visse etnisk andet mærkede til at agere på det begær, der kan være knyttet til skolekundskaber, og som man føler sig afskåret fra at forfølge qua sin kategorielle henvisthed - altså at agere på denne situation ved at vende begæret destruktivt mod læringsrummet. Eller tænk på drengegrupper i skolegården, der pludselig og tilsyneladende umotiveret vælter ind i en gruppe individer, der gør pigelege. I vil se et utal af sådan nogle bestræbelser på at ødelægge det, man qua konnotationsmønstrene er udelukket fra at deltage i: Slottet kan smadres, legene kan obstrueres, forholdemåder og æestetiske udtryk bagtales. På ledelsesplan i organisationerne kender vi det som mistænkeliggørelse, marginalisering og latterliggørelse af særlige forholdemåder og kompetencer.

3. Den tredje mulighed er interessant og måske også den, der rummer et bevægelsespotentiale med lidt mere langtrxkkende ændringsperspektiver end de to forgående. 
Strategien indebærer udnyttelsen af en bestemt mulighed nemlig den, at man kan nærme sig typer af feminint konnoterede genstande og forholdemåder, hvis man medbringer tilstrækkelig mange tegn på, at man realiserer maskuliniteten adækvat altså tilstrækkelig mange tegn til, at man ikke risikerer at få sin maskulinitetsrealisering og dermed sit kategoritilhør, mistænkeliggjort; at få det delegitimeret. De tegn, man kan medbringe, kan have forskellig karakter: Det er ikke nok bare at tegnsætte fysisk, som det sker i forudsætningen af genitalt udstyr; heller ikke nok med tegnsætningen i frisurer, tøj, måder at bevæge kroppen på. Kropstegn er væsentlige og må være der, men de er ikke nok; der må mere til.

Det, der til gengxld summer op, så det fungerer, er for det første, hvis man medbringer maskulint konnoterede genstande våben, for guds skyld, på det her tidspunkt, som 4-5 årig. Våben eller monstre og uhyrer af forskellige arter. I andre aldersgrupper kan det være andre typer af maskulint konnoterede genstande, typisk særlige former for transportmidler eller avanceret elektronisk udstyr. Men på dette tidspunkt altså våben og monstre. For det andet kan det handle om forholdemåder: Figurerne må leges med på bestemte måder, de må gøre bestemte ting, for at legitimiteten er på plads. Nogle figurer må behandles særdeles hårdhændet, og der må bruges meget høje og voldsomme lyde imens. Omsorg til gengæld kan kun udvises for f.eks. dinosauer-børn og monsterbørn (og her kan flere maskulint mærkede samarbejde om at tilrettelægge omsorgen, og der kan bruges små blide lyde imens), mens lignende omsorg for menneskebørn i dukkeversion er helt udelukket. Konkrete forholdemåder fremviser således adækvat håndtering af kønskoder, og dermed legitimt tilhør til kategorierne.

Den sidste og meget vigtige ting er, at man må medbringe sine relationer. Man må eksponere sin relationspraksis. Det er stort set umuligt at gå til det lyserøde slot alene, hvis man bliver observeret. Men man kan gå til det som relation, altså to eller tre drenge på én gang der bærer maskulinitetsidentiteten i frllesskab, og som yderligere, som jeg nævnte det før, supplerer med maskulint konnoterede genstande og eksplicit fremvisning af maskulint konnoterede forholdemåder. Med sådan et udstyr af specifikt konnoterede relationspraksisser, genstande og forholdemåder kan maskulinitetsgidsler tage sig adgang til lyserøde legoslotte - og de kan give sig hen i nydelse ved at lege med dem, ved at gøre de muligheder der ligger i dem. Nogle gange kan de endda også medbringe genstande fra de lyserøde legoslotte til det maskulint konnoterede ridderhjørne i børnehaven uden fare for delegitimering.

\section{SAMME DYNAMIKKER I ET ANDET HANDLEFELT}

Herfra kan I lade tankerne flyve: Hvad giver maskulinitetsgidsler adgang til feminint konnoterede skolefag? Til feminint konnoterede universitetsstudier fx? De universitetsstuderende, jeg interviewede til min disputats, havde mange balanceringsmanøvre aktiveret, hvis de som mandligt mærkede $\mathrm{fx}$ skulle knytte sig engageret til feminint konnoterede typer af fag, studieobjekter eller typer af videnskabelige metoder. Alt, hvad der kunne identificeres som blødt (og her skal man huske, at kønskonnotationer typisk bevæger sig i afledte og associerede begreber; man behøver ikke at udtale 'kvindelig' og 'mandlig' for at kønskonnotere; oftest bruges der faktisk i dag andre dis-tinktionsbetegnere, som fx netop 'blød' versus 'hård'; men der kan være så mange andre muligheder). Men altså: Alt hvad der kunne identificeres som 'bløde' fag, 'bløde' metoder ville kræve balancering på andre udtryks- og handledimensioner, ifald de skulle realiseres af mandligt mærkede, uden at dette ville fungere prestigesænkende for den pågxldende person. Det ville så variere med konteksten, hvilke typer af udtryk, der 
kunne kompensere: skægstubbe, fodboldsinteresser, sexistiske vittigheder, ejerskab til særlige transportmidler, andre typer af kompetencer og interesser etc. Det varierer med konteksten, men også med andre kategorier, som fx social klasse, alder og etnicitet.

På samme måde kan vi spørge: Hvad giver de kvindeligt mærkede adgang til maskulint konnoterede ledelsesposter i erhvervslivet? Hvordan kan de forstå sig selv? Hvordan kan andre forstå dem og bane veje for dem, som relevante deltagere i det handlerum? Hvordan kan det gøres? Vi kan konstatere, at det i nogle tilfælde gøres, men hvordan kan det gøres? Og hvordan kan det gøres med den selvfølgelighed, der vil kendetegne kernedeltageren? For I må regne med, at kernedeltageren $\mathrm{i}$ et bestemt handlerum eller en bestemt kategori også er den, der har præmissættende autoritet. $\mathrm{Og}$ når vi når til ledelsesniveauerne, så er det eksistensnødvendigt at blive læst og anerkendt som præmissætter. Det er eksistensnødvendigt at blive læst som kernedeltager, fordi ledelsesfunktionen baserer sig på den præmissættende autoritet. Kan man ikke blive læst som præmissættende kernedeltager, så er man ude af kategorien - så er man ikke noget lederemne.

Derfor er spørgsmålet væsentligt: Hvad skal den feminint konnoterede medbringe her, for at blive læst som relevant kernedeltager? Hvis nu hun medbringer smykker, høje hæle og nogle bestemte feminint konnoterede forholdemåder, fx noget, der bliver forstået som en dialogisk kommunikationsstil, en hensynstagende og indfølende relationspraksis - så passerer det formentlig som bekræftelse af tilhøret til den passende kønskategori. I forhold til kønsaspektet bliver hun ikke den forkerte. Her bliver hun ikke monster. Men fungerer sådan noget også som bekræftelse af tilhøret til ledelseskategorien? Nej, her passerer den form for medbragte artefakter, udtryk og handlemåder ikke bekræftende. Ok, må vi så spørge: kan hun så lægge dem væk? Nej, endelig ik- ke. Gør hun det, bliver hun uigenkendelig som køn, og dermed som forståeligt menneske, som sympatisk person. Hun bliver, som en af de ledere jeg interviewede i et af mine projekter, hun lægger de kvindeligt konnoterede udtryk, artefakter og handlemåde bort (og jeg citerer): “en mand, og dermed usynlig, een man ikke ser og kommunikerer med". Men selvom dette kan udtales om hende, så bliver hun jo så heller ikke nogen ordentlig mand. Det er derfor, hun bliver usynlig; hun bliver ingenting; $\mathrm{i}$ nogle tilfælde upassende, inappropriate.

$\mathrm{Nu}$ kan der jo være sket det, at hun har fået bevæget sig et sted hen, hvorfra hun kan diktere beslutninger; og så er der en vis ledelseseffekt, selvom hun som person er upassende. Men her er der tale om noget helt andet end det at have den adgang til ledelsesautoritet, der består $\mathrm{i}$ at være generelt præmissættende $\mathrm{i}$ forhold til de måder at forstå og tænke på, som præger en virksomheds aktiviteter; altså noget andet end at være den, der kan fortælle situationen og målene på måder, der bare generelt vinder autoritet i de ansattes forståelse af, hvad det er, der skal foregå, og hvorfor det skal foregå. Den langsigtede og mere gennemgribende ledelsesposition forudsætter adgang til den autoritet, der bygger selvfølgelighed ind i det, der derefter opfattes som de ansattes selvstændige initiativer og beslutninger. Og det er en helt anden ledelsesautoritet, end den der går på at diktere beslutninger.

Dette er, som I kan se, også et tidsbillede. I kan fornemme Foucaults begreb om governmentality i beskrivelsen og hans tanker om tidens væsentlige magtformer som flyttet fra direkte statslige diktater til installeringen af selv-teknologier, der sikrer, at de respektive deltagere mestrer at styre sig selv inden for de angivne rationaliteter. Det er parallelt til denne governmentality-tendens, at min interviewperson taler om forskellige former for ledelsesautoriteter. Og det er så den præmissættende autoritetsform, som interviewpersonen her fortæller mig, at den 
kvinde, der ikke gør køn rigtigt, aldrig vil kunne opnå, fordi hun bliver usynlig og usympatisk. Hun bliver monstrøs. Men samtidig fungerer altså de tegn, hun har mulighed for at medbringe som potentielt undergravende for selv samme autoritet. Derfor forestår der hende en balanceringsopgave af dimensioner, ifald hun alligevel søger ind i positionen: Ok, smykker og outfit, vigtigt for legitim gøren af køn, men hvad for noglen smykker og hvilket outfit, hvilket ledelsesområde, hvilke forholdemåder i hvilke sammenhænge, hvilken form for eksponering af hvilken kompetence? Hvordan gøre det kompetitive, når kompetitivt tolkes som ukvindeligt, men som krumtap i genkendelse af ledelsestalent? Hvordan gøre dominans, når dominans tolkes som frastødende hos en kvindeligt mærket, men som helt centralt for genkendelse af et lederemne? Hvordan afgrænse det feminint konnoterede af alt det netop nævnte på en måde, som fremviser, at man mestrer det at kontrollere det feminines udstrækning og holde det borte fra de relationer og de handlerum, hvor det i særlig grad kommer til at fungere undergravende for aflæsning af ledelseskompetence? Og intet, eller i hvert fald meget lidt af dette, vil selvfølgelig være eksplicit reflekteret. Balanceringen skal forekomme autentisk for at virke, og det gør den bedst i selvfølgeliggjort og ureflekteret form.

Så langt så godt. På dette tidspunkt i forelæsningen skal jeg understrege to ting.

\section{KøN ER EKSEMPLARISK}

Køn udgør blot én kategori blandt mange. Den er en ganske gennemtrængende og stærk betydningsætter af arten; men den er ikke den eneste. Den er ikke altid aktiveret og den er ikke altid den mest dominerende. At være den der har adgang til at aktivere kategorien med dens potentialer for at positionere andre hierarkisk eller positionere dem med hensyn til større eller mindre relevans inden for givne felter - at være den, der har adgangen til at afgøre om og hvornår en sådan aktivering skal ske, kan imidlertid være ganske magtfuldt.

Eksempler: Hvornår i den faglige diskussion blandt ledere kan det være strategisk velanbragt at antyde køn i forbindelse med den kvindeligt mærkede kollega, man er uenig med? 3 Hvordan kan den således udpegede 'rense sig' (for den kønnede markering) igen med henblik på at opnå neutral status og dermed neutral autoritet på linie med de øvrige ikke-markerede deltagere i diskussionen? Gives der strategier til 'renselse', som ikke blot gør ondt værre og 'fedter' den mærkede yderligere ind i sin mærkning? Spørgsmål som disse er væsentlige; men de bygger netop på en forståelse af kategorien, der både implicerer kundskab om, hvordan den fungerer, når den er aktiveret, og kundskab om den magt, der kan være knyttet til adgangen til at regulere dens mere eller mindre omfattende aktivering $\mathrm{i}$ givne kontekster. Med den adgang åbnes nemlig muligheden for at regulere på de positioneringer, som køn er infiltreret i af både hierarkiserende art og mere indholds- og tematisk specifik art. ${ }^{4}$

Under alle omstændigheder, køn er blot een kategori, og selvom den altid vil være potentielt aktiverbar, og dermed kan udgøre en stærk betydningssætter i enhver sammenhæng, så er den ikke altid nødvendigvis den mest aktive eller den mest dominerende i den givne kontekst. Jeg ved, at kønskategorien kan være forfærdelig provokerende at se analyseret - fordi vi alle er tvunget ind $\mathrm{i}$ at leve den, og det kan være vanskeligt at se de selvfølgeligheder, man lever igennem, åbnet for refleksion. Derfor er det også lidt vigtigt at sige, at de mekanismer, der er knyttet til kønskategorien og dens funktionsmåder, har en mere generel udstrækning i forhold til andre kategoriserings- og differentieringsprincipper. Læs Dorthe Staunæs i forhold til etnicitet, seksualitet, alder og køn. Læs Jette Kofoeds arbejder i forhold til etnicitet, nationalitet, køn og alder. I vil se mekanismerne arbej- 
de, dynamikkerne, hvervningerne, minoriseringer og majoriseringer arbejde på kryds og tværs af disse kategorier. Så hvis det er for slemt at høre om køn - så paralleltænk til andre kategorier, fx etnicitet.

Det, vi fx ser i skolerne i øjeblikket, er, at også etnicitetskategorien går ind og klæber sig konnoterende til fag og til forskellige handlerum i skolekonteksten. Skolegården er et fuldstændig oplagt eksempel med dens etnisk adskilte lege- og hænge-ud-grupper. Men det gælder også læringsrum. I LivMette Gulbrandsens studie af norskundervisning i en række skoler i Oslo, viser hun meget smukt den bevægelse, der, hen over nogle år, foregår i forhold til adskillelse af ikke bare etnisk norske og etnisk andre. Det sker ikke kun i forhold til hvilke læringsrum, de opfattes og opfatter sig selv som tilhørende, men det er også en udskillelse, som krydser ind over forskellige underkategorier i forhold til de, der er positioneret som etnisk andre og i forhold til køn. fx bliver det muligt for de piger, der er mærket som etnisk andre, at bevæge sig væk fra de sprogligt rettede læringssammenhænge, hvor de etnisk andre er anbragt, og over i de etnisk norske læringssammenhænge - og det gør de ved at koble sig til de nye konnotationer i skolesystemet, som stiller en tolkningspraksis til rådighed for piger som potentielt fagligt dygtige. Mens de drenge, der er mærket som etnisk andre, bliver tilbage i de etnisk konnoterede læringssammenhænge, hvor de i fint samarbejde med skolernes øvrige aktører intensiverer den form for maskulinitetsperformance og etnicitetsperformance, som bekræfter deres anderledeshed og udelukkelse fra det etnisk norske læringsrum. Den asiatisk mærkede dreng har til gengæld et vist spillerum qua den ambivalens, der knytter sig til hans mærkning ('etnisk anden' eller 'norsk'?). Over tid bevæger han sig imidlertid ind $i$ handlerummet for de etnisk mærkede: etnisk anden lukkes her med maskulinitetskategorien som hjælpeaspekt. Den slags studier er ikke alene forsknings- mæssigt interessante; de udgør kundskabstilbud om indsigt i konnotationspraksisser med store sociale og menneskelige konsekvenser. I et socialt ansvarligt velfærdssamfund er de derfor ikke bare interessante, men også meget nødvendige.

Men det var altså den ene ting, jeg ville understrege, nemlig at konstitueringsdynamikkerne ikke er forbeholdt køn. Det, jeg i forelæsningen har gjort, er, at eksemplificere dynamikkerne gennem kategorien køn. Køn er i denne sammenhæng et meget tydeliggørende eksempel.

\section{SUBJEKTIVERING ER GENNEMGRIBENDE} OG SANSELIGT INDLEJRET

Den anden ting drejer sig om processernes karakter. Subjektiveringsprocesser skaber ikke marionetter, men handlende subjekter inden for de diskursive konstitueringsvilkår, som til enhver tid, og i stadig bevægelse, former sig i og på tværs af kontekster. Når Judith Butler derfor taler om køn som performance, er det en teoretisk begrebsligg $\varnothing$ relse, der kan bruges til at forstå den reproduktions- eller ændringseffekt, som særlige subjektiveringer bærer med sig. Når man gør køn som en del af den subjektiveringsproces, man er involveret i livet igennem, så deltager man også i processer af rekonstituerende, ændrende eller, kald det, diskursivt producerende art. Det, Butler har fat i med begrebet, er (blandt meget andet) diskursens produktive effekter, sådan som produktionen medieres af subjektiverede mænd og kvinder. Det betyder derfor ikke, at subjektiveringsprocesser kun består i effekter, men former kød og blod, følelser, sanselig orientering, praksisser, tænkemåder - subjektivering ville netop aldrig have den gennemgribende effekt, hvis processen kun havde teatralsk karakter, og hvis den var ekspliciteret og kontrollerbar på et rent strategisk niveau. Det er den ikke.

Hvis vi kort vender tilbage til de 4-5 årige maskulinitetsgidsler, så er det jo fuldstændig fascinerende at se sådan et barn 
synke på knæ foran sin knagerække i børnehaven, løfte armene mod himlen i afmagt, mens mellemgulvet tydeligvis krymper sig sammen i et kropsligt ubehag, der får underlige kvalmelyde til at bane sig vej ud af barnets mund. Hvorfor? Fordi nogen har hængt et lyserødt hårbånd på hans knage. Subjektiveringen her rummer en fuldstændig kropsliggjort, sanselig orientering i forhold til det kategorielt illegitime. En mere moderat udtrykt, men ikke mindre kropsligt oplevet reaktion, kan man se hos voksne mænd, hvis nogen foreslår dem at iføre sig nylonstrømper og neglelak. Jeg kunne have valgt så meget andet kvindeligt konnoteret som eksempel, men nu valgte jeg altså nylonstrømper og neglelak, fordi jeg tør vædde med at hver og en af jer, der sidder her, kan mærke hvad der sker. Det er en kropslig indlejret fornemmelse af kategoriel monstrøsitet. 5

Lad os nu antage, at der kom en Marsmand herned, en som overhovedet ikke kendte til selvfølgelighederne i vores subjektiveringsformer, og han så spurgte: "Hallo, hvad er det med de der lange bløde plastikagtige hylstre, der får den fyr til at reagere på den måde?" Ja, så må vi jo svare: "Du, det du ser, er konnotationspraksisser med subjektiveringseffekter. Ja, du forstår det nok ikke, Marsmand, men konnotationspraksisser er sanseligt indlejrede og har en meget stærk og gennemgribende effekt også på folks kropsligt sanselige oplevemåder og orienteringsmåder." Så siger Mars-manden: "Det forstår jeg ikke, jeg spørger ham selv, hvad det handler om." Og så må vi sige: "Jamen du får ikke noget at vide, for han ved det ikke selv. Han vil svare fra et sanseligt plan: 'Det er ulækkert'. 'Det er frastødende'. 'Det er ækelt'; og det bliver du jo ikke meget klogere af. Så, Marsmand, hvis du virkelig vil vide, hvad det handler om, så er en af de muligheder, du har at prøve, om du kan blive én af hans slags. Du må nærme dig zonen for de subjektiveringseffekter, han skaber sig igennem (sic!), og så må du reflektere over processen undervejs. Det er det, nogle af antropologerne kalder for selvinvestering som metode. Men du må slippe subjektiveringen, inden du selv er gennemsevet af dem. Når først du selv er velsubjektiveret, når du først selv er blevet del af kategorien, så kan du heller ikke se noget. Så er du nået dertil, hvor du også selv kun kan sige: 'Ad'! Så hvis du på det tidspunkt stadig er interesseret $i$ at finde ud af, hvad det handler om, så skal du have fat i helt andre typer af redskaber, hvis du skal forstå, hvad der foregår." Det, jeg forsøger at forklare Marsmanden her er, at uvidenhedsformer varierer. Forskellen mellem Marsmanden og den velsubjektiverede mand, når det gxlder uvidenhedsform, er f.eks., at Marsmandens uvidenhed rummer et potentiale af genuin nysgerrighed, mens den velsubjektiverede mand oplever det værende som så selvfølgeligt, at der ikke er nogen grund til at vide noget om det på andet end et sanseligt konstaterende niveau. Det var lige en lille metodeekskurs.

Men pointen her var at understrege, at subjektiveringens udstrækning er gennemgribende, og indbefatter sanselig og kropslig orientering. Det er jo også derfor DPUs nye forskningsprogram om sanselig orientering, som Anne Maj Nielsen skal lede, er et utroligt vigtigt element i vores universitetssammenhæng med den mere mættede forståelse af pædagogik, som nævnt tidligere.

\section{ÆNDRINGSPROCESSER OG NYE IDENTITETER}

Det sidste aspekt af denne type af faglighed, handler om ændringsprocesser og om nye identiteter. Identiteter udgør i en eller anden forstand hinandens mulighedsbetingelser. Det er i skæringspunkterne mellem allerede kendte identiteter og i forhandlingerne af dem, at der opstår nye identiteter. Det kan også være gennem nye muligheder for materiel processering, at de nye identiteter opstår. Tænk fx på on-lineteknologierne, som hele tiden udvikler sig, og de ram- 
mer der er for at gøre identiteter i chatrooms og MUDs (Multi User Dungeons), hvor ingen har mulighed for direkte at aflæse og tolke hinandens kropstegn. Deltagelse her giver muligheder for nye erfaringer og for opfindelse af nye skæringspunkter og nye positioneringer. Sådan nogle typer af dynamikker kan blandt meget andet bidrage til transformationer ind i nye identiteter. I den forbindelse er det interessant, at det engelske forskningsråd for samfundsvidenskab og økonomi (Economic and Social Research Foundation) har bevilliget, hvad der svarer til 47 mio. danske kr. til et forskningsprojekt om identiteter, nye identitetspraksiser, social handling og politik: Identities and Social Action er hovedoverskriften. Motivationen er blandt andet, at nye identiteter har omfattende social, kulturel og samfundsmæssig betydning. Og - det er noget af det, som ydermere har fået dem til at udpege en diskursanalytisk, konstruktionisk og empirisk arbejdende psykolog fra Faculty of Social Sciences, Open University (Milton Keynes, England), som leder af projekterne, nemlig Margareth Wetherell. For sagen er jo, at vi skal ind i nogle særlige kompleksitetslag for at forstå nye identiteter og deres dynamikker.

Når man snakker om subjektivering under ændring og nye identiteter, så er det vigtigt at være opmærksom på, at hvervningen, det at blive kaldt til identitet nogle ville bruge Althussers begreb om interpellation her - ikke bare foregår gennem udpegning af en person som 'identitet'. Det er også processer, der forløber gennem andres positioneringer omkring den, der kaldes til 'identitet'. Andres positioneringer bidrager til kompositionen af tilgxngelige subjektpositioner inden for et handlefelt, og de bidrager til karakteren af de positioneringshenvisninger, som enkeltpersoner og grupper af personer må orientere sig i forhold til, hvad enten de nu væsentligst finder på plads i overensstemmelse med henvisningerne, eller på forskellige måder og i forskellige grader får modsat sig dem.
Nogle eksempler:

- Ledere har brug for underordnede, der performer underordning på den rigtige måde, for at de kan positionere sig som ledere. - 'Sen performer' bliver til igennem muligheden for gensidig positionering vis a vis kategorien 'tidlig karrierestræber'.

- 'Indvandrer', 'perker' bliver til vis a vis dansker.

- 'Mand' bliver til igennem muligheden for at gøre 'mand' i konteksten af 'kvinde'. 'Mand' er dybt afhængig af, at nogen vil gøre kategorien 'kvinde' genkendeligt - for ellers falder hans kategori fra hinanden.

- 'Mand' er afhængig af, at nogen anvender kønnede konnotationspraksisser i forhold til fag, typer af kompetence, forholdemåder osv. Fordi? Fordi 'mand' ingenting er i sig selv, men udelukkende konstitueres i sammenfiltringen af maskulinitetskonstruktioner med andre konstruktionsfænomener, som fx kønskonnoteringen (femininisering og maskulinisering) af fag, kompetencer, jobpositioner, hierarkiske positioner, artefakter etc.

Gilles Deleuze er et relativt nyt bekendtskab for mig, men hans tilbud om metaforer til at tænke den her type af sammenfiltringer som linier og dimensioner i stadig bevægelse, igennem er ganske brugbare i denne sammenhæng. Han siger: forlad træmetaforen med dens føringer i forhold til at tænke $\mathrm{i}$ årsag og virkning, dybde og overflade, begyndelse og slutning - drop den og tænk i stedet i græs, i rhizome, som en sammenfiltring uden begyndelse og slutning, men bestående af linier og bevægelsesretninger, der, når de skifter dimensioner, faktisk betyder, at andre linier og sammenfiltringer undergår forandringer. Deleuze taler også om plateauer, som regioner af intensiteter, hvor alle disse bevægelsesretninger og linier samler sig midlertidigt i en mere intens kraft. Svarende til det begreb om platforme for konstruktionsbevægelser, som jeg brugte i Tegnet på Kroppen (1996). Der er mange ting at indvende mod De- 
leuze blandt andet hans noget indsnævrede og derfor afvisende forståelse af subjektiveringsbegrebet og ikke mindst hans manglende kapacitet eller vilje til at differentiere mellem bevægelsesliniers effekter i de her rhizomes. Det sidste er noget af det, der gør, at det i hvert fald ikke bliver fra ham, man kan få hjælp til at forstå etablering af hierarkier, men sådan noget kan man altid reparere på i sin egen brug af metaforer. Under alle omstændigheder er hans rhizomatiske mønstre gode at tænke nye identitetsformer med. De er også gode til at kvalificere et centralt begreb, når vi taler kategorier, nemlig begrebet om intersektionalitet. Jeg kan kun lige nå at antyde hvordan - igen med udgangspunkt i et eksempel.

En af de ledere, jeg har interviewet, havde en meget eksplicit kønnet konnotationspraksis klæbet til ledelseskompetencer. I kender den godt - den følger en diskursiv form, som har haft en vis udstrækning ganske længe. Han forklarer den på den måde, at den mandlige ledelsesform indebærer et stærkt konkurrencemoment. Det handler om at vinde, at få ret, at sejre, ikke lide nederlag og at overordne sig andre mænd. Den kvindelige ledelsesform handler om i en eller anden grad at få det, som man vil, men uden at ydmyge andre. Man tilstræber resultater, men gennem bevægelser der snarere har sideordning end overordning som mønster. Og der er selvfølgelig mange flere aspekter i fortællingen. Men det er heller ikke så meget indholdet i denne her konnotationspraksis, der er det interessante. Det interessante er at følge principperne i hans konnotationspraksis. Han siger nemlig, at den modne leder tager nogle af de kvindelige strategier til sig. Da jeg derefter spørger, om ikke det betyder, at der også åbnes rum for flere kvindelige ledere, fordi man så at sige anerkender de kvindelige strategier jeg ville selvfølgelig i mit analytiske sprog have sagt, at hvis det kvindeligt konnoterede anerkendes som adækvat i konteksten, så må man formode, at kvindeligt mærkede individer som dem, der udpeges til hovedbærere af det kvindeligt konnoterede, også i højere grad vil få adgang til den kontekst - men det er ikke analytisk sprog, jeg interviewer ved hjælp af. Så jeg spørger altså, om ikke det kan tænkes at betyde flere kvindelige ledere. Men til det siger han nej! Der vil ikke komme flere kvindelige ledere! Fordi mændene gør det kvindelige bedre end kvinderne.

\section{KONNOTATIONER I BEVÆGELSE}

Kan I se, at den konnotationspraksis er enormt interessant? Hvis vi hurtigt skiller den ad, så kan vi se, at grundpræmissen består i at kønskonnotere ledelsesstrategier. Og det er, hvad det er. Det kender vi. Det, han gør, er som et første udgangspunkt altså at reproducere strategiernes tilknytning til kropstegn (kvindelige strategier i kvindekroppe, mandlige strategier i mandekroppe). Næste skridt bliver en løsnelse af denne tilknytning. Nu kan kønnede strategier passere den grænse, kropstegnene sætter: kvindeligt konnoterede strategier kan passere over i mænd, når mænd modnes. Og her må vi jo tænke: Ups hvad sker der nu i den diskursivering, han anvender? Bliver mændene til kvinder? Bliver ledelse kvindeligt konnoteret? Omkonnoteres de tidligere kvindeligt konnoterede kompetencer, så de bliver mandligt konnoterede? Mister kønskonnotationerne kraft? Eller hvad kommer der til ske? Ja altså, der kommer ikke til at ske noget af det her - nej for tredje skridt bliver at aktivere den konnotationspraksis, som knytter mænd selvfølgeligt til ledelsespositioner, lidt mere generaliseret, til dominans - og herfra at omslutte de kvindelige strategier realiseret i mandekroppe som en bekræftelse af sammenknytningen af mandligt kropstegn og ledelsesfunktioner. Hvordan? Jo, ved at foretage en rediskursivering og erklære, at mænd gør det kvindelige bedre. Ganske enkelt! Dominans som maskulint konnoteret kommer i sammenfiltringen her til at tone over de 
konnotationspraksisser, der er knyttet til forholdemåder, og det sker uden at forholdemåder mister deres kønskonnotationer.

'Mand' kan, som I ser her, gå til det kvindeligt konnoterede og hente aspekter ud, og bringe dem ind $\mathrm{i}$ realiseringen af maskulininitetskonnoterede praksisser uden, at konnotationerne, af hverken disse praksisser eller de hentede aspekter, mister deres kønnethed.

Her kan vi så sende en venlig tanke til det lyserøde legoslot, strategi 3. Det spørgsmål, der selvfølgelig melder sig er: Hvor længe ville sådan en konnotationsstrategi kunne holde, hvis den blev mere udbredt? Ville de kvindeligt konnoterede kompetencer realiseret af mandligt mærkede kunne bevare den kvindelige konnotation, eller ville de æendre konnotation? Flyder konnotationerne sammen, så de opløses og må gendannes i nye former? Som så kan invitere til subjektivering og blive et udgangspunkt for nye identiteter? Og hvad ville der ske, hvis vi blandede etnicitet ind her? Hvis nu det var forskellige underordnede kategorier, der skulle vurderes for deres ledelseskompetencer? Hvis det var måderne, kvinder leder på, stillet over for måderne indvandrermænd leder på? Eller indvandrerkvinder leder på? Det gør de jo ikke endnu på topplan, men det er kun et spørgsmål om tid, før det er den form for konnotationssammenstød eller sammenfiltringer, der kommer i spil. Vil etnicitetskategorierne så gå ind og tone over køn, så køn bliver mindre aktiv som konnotationskraft? (Det er faktisk en af hypoteserne i det engelske projekt, at køn mister konnotationskraft) Eller bliver det måske omvendt? Eller kommer der til at ske noget helt andet? Får vi nogle helt andre transformerede kategorier ud af det? Får vi nogle helt nye plateauer for konnotationsintensiteter?

\section{Nye MULigheder}

I denne inaugurale forelæsning har den professorale erklæring - pro fiteor - det ty- deligt udsagte - bestået i en særlig teoretisk/metodologisk tilgang, som knytter sig centralt til definitionen af prdagogik som et fokus på menneskelige tilblivelselsesprocesser i en særlig form for handlerum. I den forstand gælder den professorale erklæring ikke primært et afgrænset og genstandsbundet kundskabstilbud - men derimod en teoretisk og metodologisk tilgang med særlige empirisk analytiske implikationer.

\section{Noter}

1. Ordlyden i opslaget: Ved Danmarks Pedagogiske Universitet, Institut for padagogisk psykologi, er et professorat $i$ socialpsykologi ledig til besattelse. Stillingen ønskes besat med en ansøger, der har et indgàende kendskab til dansk og international socialpsykologi, specielt med henblik pa de socialpsykologiske aspekter af køn, samt social og kulturel baggrund $i$ en uddannelsesmassig sammenhang. Stillingen omfatter forskning, forskningsledelse, undervisning og administration på det socialpsykologiske område, hvad undervisning og administration angair specielt på den pedagogisk psykologiske kandidatuddannelse og på den specialpadagogiske masteruddannelse. 2. Den 1.juli 2000 trådte loven om Danmarks Pedagogiske Universitet i kraft. Samtidig ophørte fire institutioner: Danmarks Larerhøjskole, Danmarks Pedagoghøjskole, Danmarks Padagogiske Institut og Center for Teknologistøttet Uddannelse. Institutionerne blev del af den fusion, som DPU er baseret på. Det er blandt andet denne historik, der afspejler sig i forelæsningens indledende profileringsdiskussion.

3. En kønnet markering, en mærkning af en person som kønnet, kan foregå på mange måder - lige fra den lille kompliment og den søde flirt over den sjove bemærkning til den sexistiske vittighed. Resultatet er under alle omstændigheder det samme: en aktivering af køn som betydningsskabende kategori og en accentuering af deltagerne som kønnet positionerede. De, der reagerer på vittigheden (enten med latter eller protest), og de, der besvarer flirten med flirt eller afvisning, bliver uvilkårligt til deltagere i accentueringen (de 'fedter' sig yderligere ind i mærkningen).

4. Her er der altså tale om både at pege på køn som en potentialt hierarkiserende kraft og køn som den forskelssætter i forhold til handle-, udtryks-, og opleveformer (kvinder er omsorgsfulde, mænd 
er ....). Haavind kalder dette for forståelsen af køn som magt og splittelse.

5. Dermed er der selvfølgelig også lagt op til mulighederne for specifikke former for følelsesmæssige besættelser af disse muligheder, som det $\mathrm{fx}$ kommer til udtryk i praktiseringen af fetichisme, cross-dressing etc.
Dorte Marie Søndergaard, dr.philos., professor Institut for pædagogisk psykologi Danmarks Pædagogiske Universitet 